\title{
Assessing the Contribution of Containerization to the Development of Western Ports,
}

\section{Lagos Nigeria}

Author(s): Olapoju Olabisi Michael

Source: Journal of International Logistics and Trade 2019; 17(1):12-20

Published by: Jungseok Research Institute of International Logistics and Trade, Inha University

DOI: https://doi.org/10.24006/jilt.2019.17.1.012

The Journal of International Logistics and Trade is an official journal published by Jungseok Research Institute of International Logistics and Trade, Inha University, Korea. JILT welcomes manuscripts that advance the practice and science of logistics, trade, and other related fields.

Frequency: Quarterly (March, June, September, December)

Stable URL: https://www.ejilt.org

The Jungseok Research Institute of International Logistics and Trade is a specialized academic research institute representing Inha University and the Inha Foundation in Korea. The institute aims to become a representative institute in Northeast Asia in the research of logistics and trade.

Stable URL: https://jrieng.inha.ac.kr

(C) Copyright. Jungseok Research Institute of International Logistics and Trade.

This is an Open-Access article distributed under the terms of the Creative Commons Attribution NonCommercial License (http://creativecommons.org/licenses/by-nc/4.0/) which permits unrestricted noncommercial use, distribution, and reproduction in any medium, provided the original work is properly cited 


\title{
Journal of
}

\section{International Logistics and Trade}

\section{Assessing the Contribution of Containerization to the Development of Western Ports, Lagos Nigeria}

\author{
Olapoju Olabisi Michael* \\ Department of Geography, Obafemi Awolowo University, Nigeria
}

\begin{abstract}
ARTICLE INFO
Article history:

Keywords:

Containerization

Western Ports

Development

Nigeria
\end{abstract}

Received 01 December 2018

Revision received 15 March 2019

Accepted 20 March 2019

\begin{abstract}
This study assessed the contribution of containerization to the development of Western Ports, Lagos Nigeria. The aim was to assess the influence of containerization on some indices of port development such as port infrastructure development, ship turnaround time, cargo dwell time and congestion. Questionnaire was used to gather information on the contribution of containerization to change in maritime trade in the country, the influence of containerization on terminal expansion, congestion, level of investment in container port infrastructure as well as the influence of such investment on container dwell time and ship turnaround time (TAT) and the competitiveness of container terminal within Nigeria port systems and with other developed container ports of the world. Secondary data used included statistics of reports of operations of Western Ports between 2000 and 2010 as reported by NPA, as well as reports of some selected ports derived from Containerization International Year Book, which were used in this study for the sake of global reference. Summary tables and ANOVA for the analysis of the data. Results revealed a significant contribution of containerization to maritime trade relative to the ports' annual records but with no significant influence on ship turnaround time, cargo dwell time congestion which are determinants of port productivity and competitiveness. The study concluded that Western Ports have still not reaped gains of containerization and lacking in competitiveness when compared with other developed ports of the world.
\end{abstract}

(C) 2019 Jungseok Research Institute of International Logistics and Trade, All rights reserved.

\section{Introduction}

Traditionally, seaports have become a strategic economic endowment and major catalyst of globalization process (UNCTAD, 2009) as almost $80 \%$ of the total global trade volume is facilitated by ocean transportation (Shan et al., 2014). As an interface between sea and land transportation, ports have constituted a core of the transport system and the economic determinant of any state that owns them. The significance of ports has been massified by the now global maritime trade influencer called container. Containers have been described by Urry (2007) as a mobility-system which produced complex and paradoxical effects in transport system. It is the object of the most advanced form of unitization called containerization. In the purview of economic geography, containerization has been seen as a facilitator of international trade (Coe et al., 2008). The objective of containerization is to achieve optimum advantages of through-movement of freights. As described by Levinson (2006), container is at the core of a highly automated system for moving goods from anywhere, to anywhere, with minimum of cost and complication on the way. Apart from cost minimization, introduction of containerization has lowered time expended in transferring freight from manufacturer to consumer, as well as time spent in storage yard. The

\footnotetext{
* Corresponding author: Department of Geography, Obafemi Awolowo University, 22005, Ile-Ife, Nigeria;

Email: oolapoju@ oauife.edu.ng
} 
time economy is derivable from the relative ease with which freight is exchange between modes. Since its coming into global maritime transport system, maritime market has been greatly altered as containerization has provided the mechanism to expand to international markets while improving the reliability, flexibility and costs of freight distribution. At the same time, dependence of shipping lines on particular ports has reduced. Also, greater efficiency and savings have been achieved by capitalizing on the relative advantages of various transport modes on every segment of the journey and through improved coordination of various transport segments (Lingaitienè 2008; Pocklad 2007; Kazakov 2006; Kolos 2006). Efficiency created by container innovation has created an ambience of competition in the port industry. Thus, ports, especially container terminals are been challenged to adjust throughput capacity to meet demand by investing adequately in state-of-the-art cargo handling and other terminal infrastructure for container ports. Thus, the introduction of containerization into maritime industry has been considered as revolutionary as completely new ways of doing business have emerged. For instance, containerization has created a completely new means of freight distribution especially the facilitation of a shift from push logistics to pull logistics.

Generally, the introduction of containerization has led to fortune and status differentials of ports both at the national and international levels. Fortune differentials of ports have been observed to be caused by some factors which include port site characteristics, level of investment in adequate and efficient container handling infrastructure as well as the efficiency of hinterland transport system connecting the ports. A combination of these factors determines, to a large extent, ship traffic, ship berth times, ship turnaround time, cargo dwell time, frequency of ship calls at seaports, presence or absence of congestion, which are all parts of indices of a productive port.

In spite of the various objectives and benefits of containerization to maritime trade and economic development of nations with seaports, Nigerian ports are suffering from progressive decline in significance especially when compared to other thriving ports in other parts of the globe. The decline in significance in Nigerian seaports is traceable to low investment in cargo handling infrastructure, long turnaround time of ship at ports, cargo dwell time as well as its attendance port area congestion.

Western Ports were favored to have commenced the operationalization of containerization in Nigeria in the late 1960s. However, growth of containerization was slowed down by the Civil War in late 1960s and early 1970s. Again, Western Ports witnessed intense pressure occasioned by massive importation for national reconstruction as well as the dysfunctional state of other seaports which could serve as ancillary for Western Ports. In addition, before 2006 concession, Western Ports were lacking in adequate investment in infrastructure requisite to accommodate growing container business thus making them not adjustable to expanding container throughput. More so, Western Ports are lacking in terms of wellarticulated and integrated road and rail systems that provide unhindered access to the hinterland. The characteristically congested and practically impassable roads linking Western Ports are a product of overdependence on road traffic mode for cargo movements, a fete which has reduced cargo throughput and ship turnaround time (Nigerian Pots Today, 2015).

\section{Literature review}

Due to its significance as a catalyst for global maritime trade expansion, various scholars have investigated the revolutionary attributes of containerization in the maritime industry. Hayuth (1981) has established the significance of containerization at creating a structure of hierarchy in the port industry. Hayuth (1981) submitted that the demand of containerization on ships, terminals and inland carriers tend to evolve a load centre. A condition that puts some ports especially with good site characteristics at a competitive edge over others. In terms of economies of scale, containerization reduces cost considerably because of increasing introduction and usage of large container ships. According to Rodrigue (2013), a 5,000 Twenty-foot-equivalent unit (TEU) container ship has operating costs per container 50 percent lower than a 2,500 TEU vessel. Also, moving from 4,000 TEU to 12,000 TEU reduces operating costs per container by 20 percent; and system-wide, the outcome of container technology in global transportation has been cost reductions of about 35 percent. Studies have also established the revolutionary impact of containerization in terms of speed of moving freights. Speed which has been cited as a major concern of shippers (UNCTAD, 2006), has been greatly improved as modern container ship for instance, has a monthly capacity of three to six times more than a conventional cargo ship (Muller, 1995; UNCTAD, 2011). Increase in speed has been attributed to improved port infrastructure especially container handling facilities and improved terminal area and storage yard infrastructure (Bichou and Bell, 2007) - a condition that has reduced port turnaround time, especially in some developed seaports of the world from three weeks to less than 24 hours. However, Rodrigue (1999) has argued that increase in speed is a result of time gained from improved transhipment due to containerization. Thus, it is not that freight is moving faster along the respective modes servicing supply chains, but that the efficiency of transport terminals has dramatically increased the velocity of transhipments and, consequently, of supply chains. Time savings occasioned by requisite efficient port infrastructure development has led to competitive dynamism and has also offered itself as a catalyst for an increased productivity in a given port system. In another vein, container handling productivity is of obvious importance to a carrier in selecting the transshipment hub (Lirn et al., 2004; Tongzon and Sawant, 2007; Tongzon, 2008). Carriers measure productivity in terms of ship turnaround time. This productivity is determined among other things by the level of investment in infrastructure for container handling at seaports (Itoh, 2002). Thus, the port industry is witnessing an increasing amount of terminal infrastructure projects fuelled 
by the growing importance of containerization in global commodity chain (Tongzon, 2008; Song and Cui, 2014; Tovar, et al., 2015). Table 1 provides a summary of other studies on containerization across the globe, indicating the author(s), year of study, location, study title, methods and findings. Most of the studies focused on the significance of containerization to ship frequency at ports, intermodalism, terminal productivity, port competitiveness and connectivity, as well as port infrastructure development. Others have provided insight into determinants of container port choice by shippers, influence of site and situation on port favourability and strategies for development of container ports. All these studies are developmental in context and were carried out in order to reposition those ports in global maritime industry. However, most of these studies were carried out in the developed ports of countries other than Nigeria. Fewer studies have been carried out on the adoption and utilization of containerization on the development of seaports in Nigeria (Aderamo and Adeyanju, 2013; Jaja, 2011; Ukpong, 1998; Odumosu, 1998; Filani and Ikporukpo, 1987). None of these studies has been able to provide an assessment of combined influence of containerization on port infrastructure, cargo dwell time and vessel's turnaround time at ports. Thus, the goal of this study is to provide an assessment of containerization on seaports development in Nigeria.

Table 1. Summary of studies on containerization

\begin{tabular}{|c|c|c|c|c|}
\hline Author(s) & Study & Location & Method & $\begin{array}{l}\text { Findings } \\
\end{array}$ \\
\hline Wallace (1975) & $\begin{array}{l}\text { Containerization at } \\
\text { Canadian Ports }\end{array}$ & Canada & $\begin{array}{l}\text { Descriptive } \\
\text { statistics }\end{array}$ & $\begin{array}{l}\text { Containerization influences port throughput by both } \\
\text { the carrier and route characteristics }\end{array}$ \\
\hline $\begin{array}{l}\text { Filani and } \\
\text { Ikporukpo } \\
\text { (1987) }\end{array}$ & $\begin{array}{l}\text { Trends of } \\
\text { Containerization in } \\
\text { Nigeria }\end{array}$ & Nigeria & $\begin{array}{l}\text { Descriptive } \\
\text { statistics }\end{array}$ & $\begin{array}{l}\text { Produced time-dependent trend of container handled } \\
\text { in Nigerian ports }\end{array}$ \\
\hline $\begin{array}{l}\text { Fleming } \\
\text { (1997) }\end{array}$ & $\begin{array}{l}\text { World container port } \\
\text { ranking }\end{array}$ & $\begin{array}{l}\text { Selected global } \\
\text { container ports }\end{array}$ & $\begin{array}{l}\text { Comaprative } \\
\text { analysis of } 25 \\
\text { global ports. }\end{array}$ & $\begin{array}{l}\text { Site and situation combined to define the strategic } \\
\text { commercial location for container ports }\end{array}$ \\
\hline $\begin{array}{l}\text { Martins and } \\
\text { Thomas }(2001)\end{array}$ & $\begin{array}{l}\text { Container Terminal } \\
\text { Community. }\end{array}$ & United Kingdom & $\begin{array}{l}\text { In-depth } \\
\text { interview }\end{array}$ & $\begin{array}{l}\text { Containerization has created cohesion in container } \\
\text { community }\end{array}$ \\
\hline $\begin{array}{l}\text { Turner et al. } \\
\text { (2004) }\end{array}$ & $\begin{array}{l}\text { North American } \\
\text { container productivity } \\
(1984-1997)\end{array}$ & $\begin{array}{l}\text { US and } \\
\text { Canadian } \\
\text { container ports }\end{array}$ & $\begin{array}{l}\text { DEA and } \\
\text { Tobit } \\
\text { regression }\end{array}$ & $\begin{array}{l}\text { The study established the existing relationship } \\
\text { between seaports and rail industry as critical } \\
\text { determinant of container port infrastructure } \\
\text { productivity }\end{array}$ \\
\hline $\begin{array}{l}\text { Notteboom et } \\
\text { al. (2006) }\end{array}$ & $\begin{array}{l}\text { Containerization and the } \\
\text { competitive potential of } \\
\text { upstream urban ports in } \\
\text { Europe }\end{array}$ & $\begin{array}{l}11 \text { European } \\
\text { ports }\end{array}$ & $\begin{array}{l}\text { Narrative } \\
\text { techniques }\end{array}$ & $\begin{array}{l}\text { Hinterland connections, reputation, reliability, } \\
\text { quality, productivity, reasonable costs, cargo } \\
\text { generating effect, status of a frequent port-of-call, } \\
\text { etc. also substantially } \\
\text { influence a port's competitive position }\end{array}$ \\
\hline LU et al. (2010) & $\begin{array}{l}\text { Container development } \\
\text { in port of Taichung }\end{array}$ & China & $\begin{array}{l}\text { Questionnaire } \\
\text { method } \\
\text { (Perception } \\
\text { study) }\end{array}$ & $\begin{array}{l}\text { Price, incentives, marketing and direct shipping are } \\
\text { stablished as strategies used by carriers to enhance } \\
\text { container patronage }\end{array}$ \\
\hline $\begin{array}{l}\text { Veldman et al. } \\
\qquad(2011)\end{array}$ & $\begin{array}{l}\text { Determinant of } \\
\text { container port choice in } \\
\text { Spain }\end{array}$ & Spain & $\begin{array}{l}\text { Linear } \\
\text { regression }\end{array}$ & Port location is a factor of container choice in Spain \\
\hline $\begin{array}{l}\text { Song and Cui } \\
\quad(2014)\end{array}$ & $\begin{array}{l}\text { Productivity changes in } \\
\text { Chinese container } \\
\text { terminal }\end{array}$ & China & $\begin{array}{l}\text { Malmquist } \\
\text { productivity } \\
\text { index }\end{array}$ & $\begin{array}{l}\text { Technological progress was identified as major } \\
\text { growth determinant of Chinese container terminal }\end{array}$ \\
\hline $\begin{array}{l}\text { Bernhofen et al. } \\
\text { (2015) }\end{array}$ & $\begin{array}{l}\text { Estimating the effects of } \\
\text { container revolution on } \\
\text { World trade }\end{array}$ & $\begin{array}{l}\text { Cross-country } \\
\text { (157 countries of } \\
\text { the world) }\end{array}$ & $\begin{array}{l}\text { Regression } \\
\text { analysis }\end{array}$ & $\begin{array}{l}\text { Established the view of other studies that } \\
\text { containerization is a driver of 20th century economic } \\
\text { globalization }\end{array}$ \\
\hline $\begin{array}{l}\text { Dang and Yeo } \\
\quad(2017)\end{array}$ & $\begin{array}{l}\text { Analysis of major } \\
\text { container ports in } \\
\text { Southeast Asia. }\end{array}$ & Southeast Asia. & BCG matrix & $\begin{array}{l}\text { Effective operations are established as key to } \\
\text { retaining dominant position by ports in the maritime } \\
\text { industry. }\end{array}$ \\
\hline
\end{tabular}

\section{Study data}

The study area is Western Ports, Lagos Nigeria. It is one of the two administrative divisions of Nigerian ports (Eastern and Western). The Western Ports is of four components which have been fused into two major complexes. There is the Lagos Ports Complex (hence, LPC) which is an amalgam of Apapa ports and Container Terminal; and Tin Can Island Ports Complex (hence, TCIPC), an amalgam of Tin Can Island Ports and Roll-on-Roll-off ports. Of the four, the Lagos port complex is Nigeria's largest and perhaps the most important port in the West African Sub-region. However, Lagos Ports and Tin Can Island Ports Complexes are responsible for more than 65 per cent and 90 per cent of the nation's dry cargoes and liquid (petroleum) products respectively (Nigerian Ports, 2007; Nigerian Ports Today, 2015). Lagos Port Complex has an area of 200 hectares of land. Large percentage of land area in the Lagos Port Complex is for handling 
container activities (NPA, 2000). Container Terminal port is the second component of the Western port which is located within the third Apapa Wharf extension with a total port area of 44 hectares and an installed capacity of 22,000TEUs (twenty-foot equivalent units). The Container Terminal is served by six designated container berths with a total quay length of 250metres (Nigerian Ports, 2007). The third component of the Western port is the Tin-can Island Port Complex, commissioned in 1977 with a total of 13 berths covering a total length of 2185 metres. It has the capacity to accommodate up to 13 vessels at once and specializes in the handling of general cargo, container activities as well as dry and liquid bulk. Ro-Ro (Roll-on-Roll-off) port is the fourth component of the Western port. It was commissioned in 1977 as a part of the modern Tin-can Island Port Complex. The port deals predominantly with the shipping of vehicles as well as containerized cargo. (Nigerian Ports, 2007). Presently, LPC and TCIPC are made up of 9 terminals which have been transferred to private terminal operators during the federal government concession move of 2006 in order to enhance efficiency of the ports as a whole.

\section{Materials and methods}

The study made use of primary and secondary data. Primary data included the use of structured questionnaire which was administered to four key stakeholders' organizations in the seaport industry in Western Ports, Lagos, Nigeria. The stakeholders are regarded to as port community (Martins and Thomas, 2001). They included the Nigerian Ports Authority (NPA), Seaport Terminal Operators of Nigeria (STOAN), Nigerian Shippers' Council (NSC), and the Nigerian Custom Services (NCS). The selection of these stakeholders was based on their closest affinities with the total operations of seaports in the study area. All the nine (9) existing terminal operators within the Western Ports were purposively selected for questionnaire administration. Fifteen respondents were selected from each stakeholder. The purposive selection of respondents from each stakeholder was due to the fact that none of the stakeholders was ready to disclose its staff strength in number. Therefore, a total of one hundred and eighty (180) copies of questionnaire, in all, were administered to all the selected respondents from all the stakeholders (135 copies within 9 terminals and 45 to other stakeholders). The questionnaire was used to gather information on the contribution of containerization to change in maritime trade in the country, the influence of containerization on terminal expansion, congestion, level of investment in container port infrastructure as well as the influence of such investment on container dwell time and ship turnaround time (TAT) and the competitiveness of container terminal within Nigeria port systems and with other developed container ports of the world. The choice of questionnaire survey was premised on the need to take perception of stakeholders on issues of containerization and port development into perspective. As precedence, Raballand et al., (2012) used individual questionnaire to elicit information on the dwell times of cargo in Sub-Saharan African ports. Similar method was used by United Nations Conference on Trade and Development while investigating factors militating against growth of transit trade through the ports of Takoradi, Ghana (UNCTAD, 2014). In addition, Nyema (2014) applied the questionnaire method to investigate factors influencing container terminal efficiency in Mombasa entry port in Kenya.

However, out of the 180 copies of questionnaire distributed, 102 copies (56.7\%) were returned while 78 copies $(43.3 \%)$ were not returned (Table 2). The major reason for not retrieving some of the questionnaire was 'official sentiments' as some of the terminal operators were not ready to give any audience because they thought their operations might be subjected to public scrutiny through the information contained in the questionnaire. The response rate of $56.7 \%$ was justified and considered acceptable based on some empirical studies on response rate in academic studies. For instance, Baruch (1999) reported from 175 different case studies that average acceptable response rate (RR) was 55.6\% with a standard deviation of 19.7. According to him, the lower extreme RR cases were $10 \%$ and $15 \%$ while extreme upper cases were considered to be $96 \%$ and $99 \%$ respectively. In another separate study, Johnson and Owens (2013) study on survey response rate reporting in the professional literature, reported that telephone and face-to-face survey were most likely to report undefined RR of $42.9 \%$ and $31.3 \%$ respectively.

Table 2. Questionnaire distribution pattern and response rate

\begin{tabular}{ccccc}
\hline Stakeholders & No of questionnaire & Returned & Not returned & \% Returned \\
\hline NPA & 15 & 9 & 6 & 60 \\
NCS & 15 & 14 & 1 & 93 \\
SC & 15 & 8 & 7 & 53 \\
TO & 135 & 71 & 64 & 52.6 \\
Total & 180 & 102 & 78 & 56.7 \\
\hline
\end{tabular}

Secondary data was derived from statistics of reports of operations of Western Ports between 2000 and 2010 as reported by NPA. Also, reports of some selected ports were derived from Containerization International Year Book to provide some comparative references. Ports selected included Hong Kong, Rotterdam, New York and Los Angeles ports; all of which are from Asia, Europe and United States of America. Data was analyzed using descriptive and inferential statistics.

Descriptive statistics included the use of summary tables to present the annual statistics of operations of the ports. 
Inferential statistics included the use of Analysis of Variance (ANOVA) which was used to determine whether there was a significant difference between the mean responses of the various stakeholders on some selected indices of port development.

These indices are influence on maritime trade, terminal area development, terminal expansion and investment in container handling infrastructure, ship turnaround and cargo dwell time. Likert Scale method was used to represent the degree of agreement with the questions on indices of port development.

\section{Results}

\subsection{Impact of containerization on selected indices of port development}

The results of the analysis on Table 3 showed that $59.8 \%$ and $39.22 \%$ strongly agreed and agreed, respectively, that containerization has brought a significant change to maritime trade in Western Ports.

Table 3. Responses on impact of containerization on selected indices of port development

\begin{tabular}{|c|c|c|c|c|c|}
\hline Variable & Frequency & \% Frequency & Variable & Frequency & \% Frequency \\
\hline $\begin{array}{l}\text { Significant change on maritime } \\
\text { trade }\end{array}$ & & & Terminal expansion & & \\
\hline Strongly agree & 61 & 59.8 & Strongly agree & 61 & 59.8 \\
\hline Agree & 40 & 39.22 & Agree & 38 & 37.26 \\
\hline Disagree & - & - & Disagree & 3 & 2.94 \\
\hline Strongly disagree & - & - & Strongly disagree & - & - \\
\hline Undecided & 1 & 0.98 & Undecided & - & - \\
\hline Total & 102 & 100 & Total & 102 & 100 \\
\hline $\begin{array}{l}\text { Investment in container } \\
\text { loading facilities }\end{array}$ & & & Cargo throughput & & \\
\hline Very satisfactory & 5 & 4.9 & Very significant & 97 & 95.09 \\
\hline Satisfactory & 68 & 66.67 & Significant & 3 & 2.94 \\
\hline Not satisfactory & 29 & 28.43 & Not significant & 2 & 1.97 \\
\hline Total & 102 & 100 & Total & 102 & 100 \\
\hline Competitiveness within & & & Competitiveness with & & \\
\hline Nigerian port system & & & developed ports of the world & & \\
\hline Highly competitive & 96 & 94.12 & Highly competitive & - & - \\
\hline Competitive & 6 & 5.88 & Competitive & 36 & 35.29 \\
\hline Not competitive & - & - & Not competitive & 66 & 64.71 \\
\hline Total & 102 & 100 & Total & 102 & 100 \\
\hline Effect on congestion & & & Effect on TAT of ships & & \\
\hline Improved & 10 & 9.8 & Improved & 57 & 55.88 \\
\hline Worsen & 89 & 87.26 & Worsen & 45 & 44.12 \\
\hline Uncertain & 3 & 2.94 & Uncertain & - & - \\
\hline Total & 102 & 100 & Total & 102 & 100 \\
\hline \multicolumn{6}{|l|}{ Effect on cargo dwell time } \\
\hline Improved & 18 & 17.65 & & & \\
\hline Worsen & 84 & 82.35 & & & \\
\hline Uncertain & - & - & & & \\
\hline Total & 102 & 100 & & & \\
\hline
\end{tabular}

On the influence on terminal area expansion, 59.8\% strongly agreed that containerization has led to terminal area expansion, $37.26 \%$ agreed, while $2.94 \%$ disagreed that containerization led to terminal area expansion. Investment in container loading facilities has been considered as very satisfactory by $4.9 \%$ of the respondents. About $66.67 \%$ has considered investments in container loading facilities as satisfactory while $28.43 \%$ considered it as not satisfactory.

In another vein, the influence of containerization on cargo throughput was seen as very significant by $95.09 \%$, significant by $2.94 \%$ and not significant by $1.97 \%$ respectively. However, $9.8 \%$ considered container technology as a measure that has improved congestion situation in Western Ports, while $87.26 \%$ has seen it as a worsening catalyst for congestion, only $2.94 \%$ was uncertain of its influence on improvement in congestion condition within the Western Ports. The turnaround time for vessel was considered as improved by $55.88 \%$ while $44.12 \%$ considered it as not improved at all. In a similar vein, $17.65 \%$ believed cargo dwell time has been reduced by containerization while $82.35 \%$ considered cargo dwell time as not reduced by any measure. Also, about $94.12 \%$ submitted that containerization has enhanced very high competition for business among the terminals within the Western Ports. About $5.88 \%$ considered the relationship as just competitive. On the contrary, the status of Western Ports in relation to other developed ports of the world was considered as competitive by $35.29 \%$ while $64.71 \%$ considered it as not competitive relative to other developed ports of the world. This is evident in the comparative analysis of Western ports container traffic and other selected ports between 
2000 and 2010.

For instance, Western Ports total container throughput in 2000 was just $1.7 \%$ of Hong Kong container terminal, $4.96 \%$ and $6.3 \%$ of Rotterdam and Los Angeles container terminals respectively. By 2010, it was just 2.64\%, 5.57\% and 7.93\% of container traffic in Hong Kong, Rotterdam and Los Angeles, respectively. In addition to the analysis shown above, Analysis of Variance (ANOVA) was carried out to determine whether there was any statistically significant variance in the means of respondents on the influence of containerization on maritime trade, terminal area development, terminal expansion and investment in cargo handling infrastructure (Table 4). These indices were selected because they were clearly stated in the concession agreement as responsibilities of the private terminal operators as well as the key drivers of regional and international trade competitiveness. The results showed that there was no statistically significance difference between the group means for all the indices selected at level of significance of 0.05; (significance on maritime trade: $F\{2,80\}=0.933, p=0.39$; terminal expansion: $F\{2,80\}=3.114 . p=0.05$; terminal area development: $F\{2,80\}=0.562$, $p=0.57$; and cargo handling infrastructure: $F\{2,80\}=1.111, p=0.33$ ).

Table 4. Significance of mean difference in perception of indicators

\begin{tabular}{|c|c|c|c|c|c|c|}
\hline & & Sum of Squares & $d f$ & Mean Square & $F$ & Sig. \\
\hline \multirow{3}{*}{$\begin{array}{l}\text { Containerization has brought significant } \\
\text { change to maritime trade. }\end{array}$} & Between Groups & 0.455 & 2 & 0.227 & 0.933 & 0.397 \\
\hline & Within Groups & 20.465 & 80 & 0.244 & & \\
\hline & Total & 20.920 & 82 & & & \\
\hline \multirow{3}{*}{$\begin{array}{l}\text { Containerization has led to seaport terminal } \\
\text { expansion. }\end{array}$} & Between Groups & 2.617 & 2 & 1.308 & 3.114 & 0.050 \\
\hline & Within Groups & 34.871 & 80 & 0.420 & & \\
\hline & Total & 37.488 & 82 & & & \\
\hline \multirow{3}{*}{$\begin{array}{l}\text { How would you assess Nigerian seaports in } \\
\text { terms of development of terminal }\end{array}$} & Between Groups & 0.367 & 2 & 0.184 & 0.565 & 0.571 \\
\hline & Within Groups & 27.621 & 80 & 0.325 & & \\
\hline & Total & 27.989 & 82 & & & \\
\hline \multirow{3}{*}{$\begin{array}{l}\text { How would you assess Nigerian seaports in } \\
\text { terms of investment in cargo handling } \\
\text { facilities }\end{array}$} & Between Groups & 0.894 & 2 & 0.447 & 1.111 & 0.334 \\
\hline & Within Groups & 34.197 & 80 & 0.402 & & \\
\hline & Total & 35.091 & 82 & & & \\
\hline
\end{tabular}

\subsection{Impact of containerization on selected indices of port development}

The challenges of port development as shown in Table 5, in order of percentage responses, included poor rail and road connectivity (88.24\%), congestion (74.5), delay in pick-up of container (66.67\%), storage yard constraint (39.22\%), quay side infrastructure (13.73\%), and documentation (11.76\%), respectively. However, suggested solutions to the observed prevailing challenges, in order of percentage response, included investment in container handling infrastructure $(96.07 \%)$, enhanced road and rail network $(90.19 \%)$, more inland container depot $(88.23 \%)$, improved cargo processing time $(80.39 \%)$ and improved information and communication technology (ICT) (65.68\%).Others included terminal area extension (41.17\%), storage yard enlargement (40.19\%)and dredging of the sea to accommodate bigger vessels (18.62\%).

Table 5. Challenges of ports development and suggested solutions.

\begin{tabular}{lc}
\hline Variables & \% Frequency \\
\hline Congestion & 74.5 \\
Delay in picking up & 66.67 \\
Documentation & 11.76 \\
Storage yard infrastructure & 39.22 \\
Quay side infrastructure & 13.73 \\
Poor road connectivity & 88.24 \\
Poor rail system & 88.24 \\
Suggested solutions & \\
Investment in container handling infrastructure & 96.09 \\
Terminal area expansion & 41.17 \\
Enlarge storage yard & 40.19 \\
Enhance road and rail network connecting ports to hinterland & 90.19 \\
Improve cargo processing time & 80.39 \\
Dredging of the sea to accommodate bigger vessels & 18.62 \\
Improve ICT within the seaport industry & 65.68 \\
Set up more inland container port & 88.23 \\
\hline
\end{tabular}

\section{Discussion}

From the results of the analysis of the questionnaire in the previous section, the cumulative $99 \%$ of respondents showing agreement with the significant contribution of containerization to maritime trade in the ports was reflected in the 
traffic of containers handled between 2000 and 2010. Though there were fluctuations in container traffic, record showed a progressive increase. For instance, the annual percentage in container traffic showed an increase of about $41.23 \%$ between 2000 and 2001 and a difference of $8.19 \%$ between 2001 and 2002 records, except 2003 when a negative percentage balance was recorded. The contribution to maritime trade could also be explained by the gesture of the government to establish, in addition to the existing Kano and Kaduna inland container depots, six inland container depots in Isiala-Ngwa (Abia state), Ibadan (Oyo state), Kano (Kano state), Jos (Plateau state), Funtua and Maiduguri (Nigerian Ports Today, 2013). Further, the contribution of containerization to maritime trade in Western Ports is a reflection of the trends of global maritime trade. For instance, significant change has been witnessed in global maritime trade since the 1990s such that, by 2009, over 90 per cent of the global non-bulk maritime trade was shipped in container (Ebeling, 2009; Worldshipping, 2012). Again, the contribution of containerization to the Nigerian ports (Western Ports) maritime trade on one hand, and to global maritime trade on the other, is as a result of increasing trade liberalization and deeper trade integration which has given path to a notable increase in commodities trade and higher volumes of import demand for capital and consumer goods (Suarez-Aleman, et al., 2016).

In terms of its influence on ports infrastructure generally, high percentage responses in favour of the significance of containerization on terminal expansion, and investments on general and container cargo handling facilities is an allusion to the significance of infrastructure and institutional framework to the overall operational efficiency of any port (African Development Report, 2010). This understanding formed the basis for the improvement in terminal and cargo handling infrastructure after the concession gesture of the federal government. Concession programme, which vested the managements of most various terminals within the Nigerian ports industry into private operators, has brought about a significant investment in infrastructure for enhancing business in the port industry. For instance, Apapa Bulk Terminal Limited (ABTL), one of the terminals within Western Ports, has so far invested over 25 billion on berth rehabilitation, land and buildings, container handling equipment, computers, plants and machineries acquisition (Nigerian Ports Today, 2015). In a similar case, AP Moller Terminal (APMT), which is the largest container terminal in sub-Saharan Africa, has since concession, invested more than USD366million on terminal improvements and about USD478million on infrastructure improvement, terminal expansion, container handling equipment and quay expansion (Nigerian Ports Today, 2015).

Further, high percentage response for cargo dwell time agrees with the high average records of dwell time of between 14-21 days in Western Ports (Beuran, et al., 2012; Ships and Ports, 2013, 2014, 2015; The Vanguard, 2013). It is also in consonance with records of dwell time in most ports of the Sub-Saharan Africa where cargo dwell time is awkwardly long, usually more than two weeks compared to a week or less in large ports of Asia, Europe and Latin America (African Development Report, 2010; Raballand, et al., 2012). Comparatively, in South Africa 93 percent of imported containers have a dwell time between 0 and 5 days, in Kenya 69 percent of its imports need between 6 and 20 days to be cleared, in Zambia, most of the imported containers (59 percent) have a dwell time between zero and five days while 74 percent of container imports in Nigeria have between 6 and 20 days to be cleared (Beuran et al., 2012). This comparison reflects the challenges Western Ports are facing in terms of competitiveness. This is because the speed at which ships can be turned around as well as number of days cargo spent at port terminals' storage yard, has significant influence on trade facilitation of the ports (Clark et al.,2004) as well as on regional development (Haddad et al., 2010).

\section{Conclusion}

This study assessed the contribution of containerization to the development of Western Ports, Lagos Nigeria. By means of questionnaire method, information was gathered on the perception of selected stakeholders on the contribution of containerization to change in maritime trade in the country, the influence of containerization on terminal expansion, congestion, level of investment in container port infrastructure as well as the influence of such investment on container dwell time and ship turnaround time (TAT) and the competitiveness of container terminal within Nigeria port systems and with other developed container ports of the world.

Findings suggested that containerization had increased trading in Western ports but when compared to other developed terminals of the world, they are underperforming. Though findings revealed that investments in container handling infrastructure have improved significantly especially since concession, much gains have not been reaped from containerization as port congestion is still not improved due to impassable road and rail networks which have also increased cargo dwell time at ports and increased the length of time ships spend at berth.

Empirically, the study has shown lack of representativeness of studies on Nigerian ports in the annals of global port studies and has thus provided an empirical assessment of Western port development in Nigeria using perception of stakeholders. However, its policy suggestion provides terminal/port handlers with veritable information for performance evaluation needed to leap into visible rung of regional and global competitive arena. As a result, this study suggests that terminal expansion and intensive investment in more state-of-the-art facilities are needed to accommodate ever increasing container throughput as is the case in other developed ports of the world. There is the need to initiate new pliable supply chains and harmonize existing ones connecting the hinterland in order to enhance attractiveness and increase the economic success of Western Ports. This is necessary for local competitiveness and the elimination of negative externalities that 
may arise from protracted inefficiency.

\section{References}

Aderamo, A.J., Adeyanju, J.A., 2013. Diffusion of container packaging method into the Nigerian transport system. Journal of Asian Scientific Research 3, 39-56.

African Development Report, 2010. Concept note for the African development report 2010 on Ports, logistics and trade in Africa. African Development Bank.

Bichou, K., Bell, M.G.H., 2007. Internationalisation and consolidation of the container port industry: Assessment of channel structure and relationships. Maritime Economics and Logistics 9, 35-51.

Clark, X., Dollar, D., Micco, A., 2004. Port efficiency, maritime transport costs, and bilateral trade. Journal of Development Economics $75,417-450$.

Ebeling C.E., 2009. Evolution of a box. Invention Technology 23, 8-9.

Filani, M.O., Ikporukpo, C.O., 1987. Containerization in Nigeria: Trends and patterns. Maritime Policy \& Management 14, $185-195$.

Fleming, D.K., 1997. World container port rankings. Maritime Policy \& Management 24, 175-181.

Grzelakowski, A., Matczak M., 2012. Współczesne porty morskie: Funkcjonowanie i rozwój. Akademia Morska w Gdyni.

Hayuth, Y., 1981. Containerization and the load center concept. Economic Geography 57, 160-176.

Haddad, E.A., Hewings, G.J.D., Perobelli, F.S., Santos dos, R.A., 2010. Regional effects of port infrastructure: A spatial CGE application to Brazil. International Regional Science Review 33, 239-263.

Jaja, C.Y., 2011. Freight traffic at Nigerian seaports: Problems and prospects. Medwell Journals 6, 250-258.

Kazakov, N., 2006. Simulation modeling of the group of multimodal cargo lines including water transport. Transport 21, 88-94.

Kolos, M., 2006. Production amalgamation's 'Belaruskali' potash delivery system analysis from logistic positions. Transport 21, 286288.

Levinson, M., 2006. The Box: How the Shipping Container Made the World Smaller and the World Economy Bigger, Princeton University Press, Princeton.

Lingaitiené, O., 2008. A mathematical model of selecting transport facilities for multimodal freight transportation. Transport 23, 1015.

Lirn, T.C., Thanopoulou, H.A., Beynon, M.J., Beresford, A.K.C., 2004. An application of AHP on transshipment port selection: A global perspective. Maritime Economics \& Logistics 6, 70-91.

Lu, C.-S., Lin, C.-C., Lee, M.-H., 2010. An Evaluation of Container Development Strategies in the Port of Taichung. The Asian Journal of Shipping and Logistics 26, 93-118.

Martin, J., Thomas, B.J., 2001.The container terminal community. Maritime Policy \& Management 28, 279-292.

Muller, G., 1995. Intermodal Freight Transportation. 3rd ed. Eno Foundation for Transportation, Westport.

Nigerian Ports Today, 2015. Port concession in Nigeria: 8 years on.... Nigerian Ports Today. A publication of Nigerian Ports Authority 4, 7-8.

Nigerian Ports, 2007. Western Ports. Nigerian Ports Authority.

Nigerian Ports Authority, 2000. Annual report of statistics. Nigerian Ports Authority.

Nigerian Ports Today, 2014. Contributions of NPA to economic development in Nigeria. Nigerian Ports Today. A publication of Nigerian Ports Authority 4, 42-54.

Notteboom, T.E, 2005. The Peripheral Port Challenge in Container Port Systems. International Maritime Transport: Perspectives, Edited by: Leggate, H, McConville, J and Morvillo, A. 173-188. Routledge, London.

Notteboom, T. E., Coeck, C., Verbeke, A., Winkemans, W., 1997. Containerization and the competitive potential of upstream urban ports in Europe. Maritime Policy \& Management 24, 285-289.

Odumosu, T., 1998. Urban dimension in Nigerian ports development: The city connection. Maritime Transportation in Nigeria, Ogun State.

Ogundana, B., 1976. Changing the capacity of Nigeria's seaport entrances. ODU: Journal of West African Studies 14, 69-88.

Pocklad, O., 2007. Development of the interurban service by use of alternative commercial road trains. Transport 22, 90-98.

Raballand, G., Refas, S., Beuran, M., Isik, G., 2012. Why does cargo spend weeks in Sub-Saharan African ports? Lessons from six countries. World Bank World.

Ships and Ports, 2013. Long cargo dwell time threatens ports operations. <http://shipsandports.com.ng/long-cargo-dwell-timethreatens-port-operation>.

Ships and Ports, 2014. FG moves to start full automation in Nigerian ports. <http://shipsandports.com.ng/fg-moves-to-start-fullautomation-in-nigerian-ports>.

Ships and Ports, 2015. The real problem with Nigerian ports. 〈http://shipsandports.com.ng/the-real-problem-with-nigerian-ports〉.

Song, B., Cui, Y., 2014. Productivity changes in Chinese container terminals. Transport Policy 35, 377-384.

Suarez-Aleman, A., Sarriera, J.M., Serebrisky, T., Trujillo, L. 2016. When it comes to container port efficiency, are all developing regions equal?. Transport Research Part A 86, 55-77.

The Vanguard, 2013. How cargo dwell time stalls trade facilitation at ports. <https://www.energymixreport.com/how-cargo-dwelltime-stalls-trade-facilitation-at-ports-report>.

Tongzon, J.L., 2008. Port Reform in Singapore: Towards Privatisation?. Port Privatisation: The Asia-Pacific Experience, edited by J. Reveley, and M. Tull, 110-119. Cheltenham: Edward Elgar.

Tongzon, J.L., Sawant, L., 2007. Port choice in a competitive environment: From the shipping lines' perspective. Applied Economics $39,477-492$.

Tongzon, J.L. Heng, W., 2005. Port privatization, efficiency and competitiveness: Some Empirical evidence from container ports (terminals). Transportation Research Part A 39, 405-424. 
Assessing the Contribution of Containerization to the Development of Western Ports, Lagos Nigeria

Tovar, B., Hernández, R. Rodríguez-Déniz, H., 2015. Container port competitiveness and connectivity: The Canary Islands main ports case. Transport Policy 38, 40-51.

Ukpong, A.M., 1998. Nigerian Seaports and the agricultural sector: Challenges from policy discontinuities. Maritime Transport in Nigeria. Ogun State.

UNCTAD, 2006. Landlocked developing countries: Facts and Figures. New York and Geneva, UNCTAD.

UNCTAD, 2011. Review of Maritime Transport. Geneva, United Nations.

Urry, J., 2007. Mobilities. Cambridge, Polity.

Veldman, S., Garcia-Alonso, L., Vallejo-Pinto, J.A., 2011. Determinants of container port choice in Spain. Maritime Policy \& Management 38, 509-522.

Wallace, I., 1975. Containerization at Canadian ports. Annals of the Association of American Geographers 65, 433-448.

Worldshipping, 2012. Top 50 world container ports. <http://www.worldshipping.org/about-the-industry/global-trade/top-50-worldcontainer-ports>. 